\title{
Identification and Selection of Major Carbon Dioxide Stream Compositions
}

\author{
GV Last \\ MT Schmick
}

June 2011

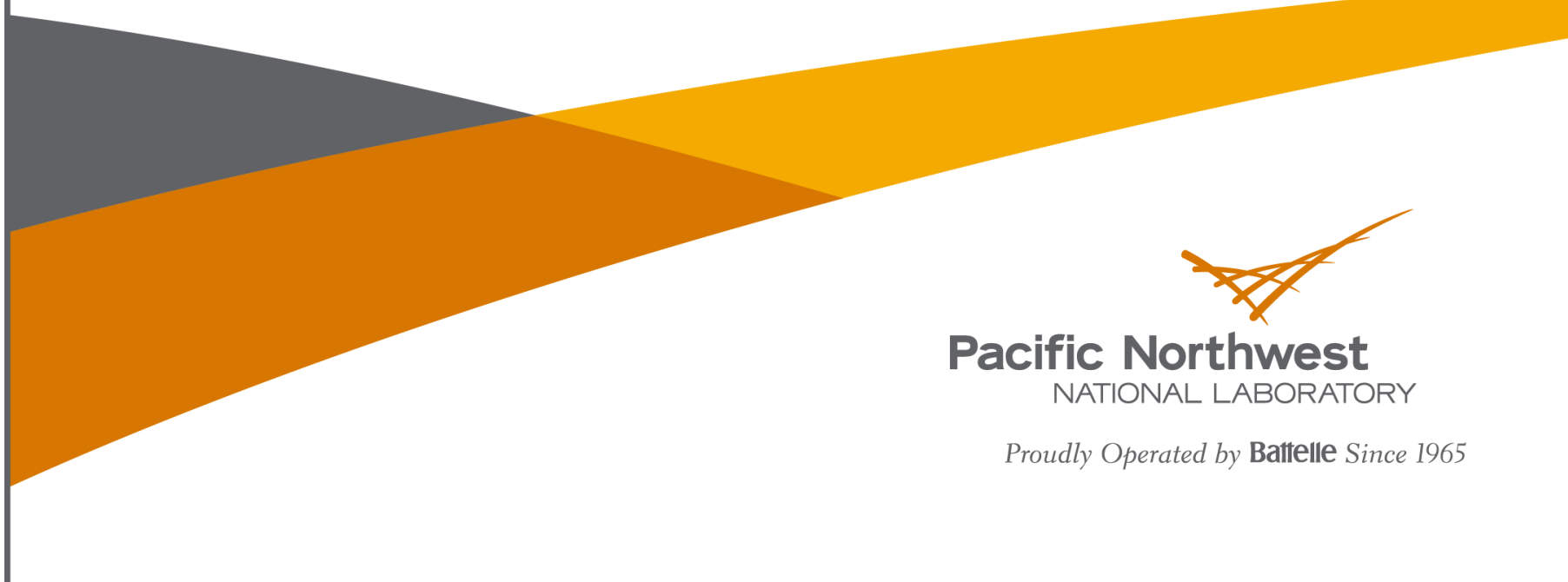




\title{
DISCLAIMER
}

This report was prepared as an account of work sponsored by an agency of the United States Government. Neither the United States Government nor any agency thereof, nor Battelle Memorial Institute, nor any of their employees, makes any warranty, express or implied, or assumes any legal liability or responsibility for the accuracy, completeness, or usefulness of any information, apparatus, product, or process diselosed, or represents that its use would not infringe privately owned rights. Reference herein to any specific commercial product, process, or service by trade name, trademark, manufacturer, or otherwise does not necessarily constitute or imply its endorsement, recommendation, or favoring by the United States Government or any agency thereof, or Battelle Memorial Institute. The views and opinions of authors expressed herein do not necessarily state or reflect those of the United States Government or any agency thereof.

\author{
PACIFIC NORTHWEST NATIONAL LABORATORY \\ operated by \\ BATTELLE \\ for the \\ UNITED STATES DEPARTMENT OF ENERGY \\ under Contract DE-AC05-76RL01830
}

Printed in the United States of America
Available to DOE and DOE contractors from the Office of Scientific and Technical Information,
P.O. Box 62, Oak Ridge, TN 37831-0062;
ph: (865) 576-8401
fax: $(865)$ 576-5728
email: reports@adonis.osti.gov

\begin{abstract}
Available to the public from the National Technical Information Service, U.S. Department of Commerce, 5285 Port Royal Rd., Springfield, VA 22161 ph: (800) 553-6847 fax: $(703) 605-6900$

email: orders@ntis.fedworld.gov

online ordering: http://www.ntis.gov/ordering.htm
\end{abstract}




\section{Identification and Selection of Major Carbon Dioxide Stream Compositions}

GV Last

MT Schmick

June 2011

Prepared for

the U.S. Department of Energy

under Contract DE-AC05-76RL01830

Pacific Northwest National Laboratory

Richland, Washington 99352 



\begin{abstract}
A critical component in the assessment of long-term risk from geologic sequestration of carbon dioxide $\left(\mathrm{CO}_{2}\right)$ is the ability to predict mineralogical and geochemical changes within storage reservoirs as a result of rock-brine- $\mathrm{CO}_{2}$ reactions. Impurities and/or other constituents in $\mathrm{CO}_{2}$ source streams selected for sequestration can affect both the chemical and physical (e.g., density, viscosity, interfacial tension) properties of $\mathrm{CO}_{2}$ in the deep subsurface. The nature and concentrations of these impurities are a function of both the industrial source(s) of $\mathrm{CO}_{2}$, as well as the carbon capture technology used to extract the $\mathrm{CO}_{2}$ and produce a concentrated stream for subsurface injection and geologic sequestration.
\end{abstract}

This report summarizes the relative concentrations of $\mathrm{CO}_{2}$ and other constituents in exhaust gases from major non-energy-related industrial sources of $\mathrm{CO}_{2}$. Assuming that carbon capture technology would remove most of the incondensable gases $\mathrm{N}_{2}, \mathrm{O}_{2}$, and $\mathrm{Ar}$, leaving $\mathrm{SO}_{2}$ and $\mathrm{NO}_{\mathrm{x}}$ as the main impurities, the authors of this report selected four test fluid compositions for use in geochemical experiments. These included the following: 1) a pure $\mathrm{CO}_{2}$ stream representative of food-grade $\mathrm{CO}_{2}$ used in most enhanced oil recovery projects; 2$)$ a test fluid composition containing low concentrations ( 0.5 mole \%) $\mathrm{SO}_{2}$ and $\mathrm{NO}_{\mathrm{x}}$ (representative of that generated from cement production); 3) a test fluid composition with higher concentrations (2.5 mole \%) of $\mathrm{SO}_{2}$; and 4) test fluid composition containing 3 mole $\% \mathrm{H}_{2} \mathrm{~S}$. 



\section{Acronyms and Abbreviations}

\begin{tabular}{|c|c|}
\hline ARRA & American Recovery and Reinvestment Act \\
\hline $\mathrm{CaO}$ & calcium oxide \\
\hline CCS & carbon capture and sequestration \\
\hline $\mathrm{CH}_{4}$ & methane \\
\hline $\mathrm{CO}$ & carbon monoxide \\
\hline $\mathrm{CO}_{2}$ & carbon dioxide \\
\hline EOR & enhanced oil recovery \\
\hline EPA & U.S. Environmental Protection Agency \\
\hline GHG R\&D & IEA's Greenhouse Gas Research and Development (program) \\
\hline $\mathrm{H}_{2}$ & hydrogen \\
\hline $\mathrm{H}_{2} \mathrm{O}$ & water \\
\hline $\mathrm{H}_{2} \mathrm{~S}$ & hydrogen sulfide \\
\hline $\mathrm{HCl}$ & hydrogen chloride \\
\hline IEA & International Energy Agency \\
\hline IGCC & Integrated Gasification Cycle \\
\hline MEA & monoethanolamine \\
\hline $\mathrm{N}_{2}$ & nitrogen \\
\hline $\mathrm{NH}_{3}$ & ammonia \\
\hline NO & nitric oxide \\
\hline $\mathrm{NO}_{2}$ & nitrogen dioxide \\
\hline $\mathrm{NO}_{\mathrm{x}}$ & nitrogen oxide \\
\hline $\mathrm{O}_{2}$ & oxygen \\
\hline ppm & parts per million \\
\hline ppmv & parts per million by volume \\
\hline $\operatorname{scf}$ & standard cubic feet \\
\hline SCR & selective catalytic reduction \\
\hline $\mathrm{SO}_{2}$ & sulfur dioxide \\
\hline $\mathrm{SO}_{3}$ & sulfur tri-oxide \\
\hline $\mathrm{SO}_{\mathrm{x}}$ & sulfur oxide \\
\hline TDF & tire-derived fuels \\
\hline VOC & volatile organic compound \\
\hline
\end{tabular}





\section{Glossary}

Calcination: A thermal treatment process typically used for decomposition of calcium carbonate (limestone) to calcium oxide (lime) and carbon dioxide.

Carbon black: A fine black amorphous form of carbon, principally used as a reinforcing agent in rubber, and as a black pigment in inks, surface coatings, paper, and plastics.

Co-contaminants: Chemical impurities found in $\mathrm{CO}_{2}$ source streams.

Coke: A solid carbonaceous material, derived from destructive distillation of low-ash, low-sulfur bituminous coal, and typically used as a fuel and reducing agent in smelting iron ore in a blast furnace.

Critical temperature: The temperature above which a gas cannot be liquefied, regardless of the pressure applied.

Desulfurization: The removal of sulfur or sulfur compounds (e.g., $\mathrm{SO}_{2}$ from exhaust flue gases).

Feedstock: Bulk raw material supplied (or fed) to an industrial process.

Flue gas: Exhaust gas (typically combustion exhaust gas from power plants) released to the atmosphere via a flue (e.g., pipe).

Interfacial tension: The surface tension at the interface between two nonmiscible liquids.

Mercaptans: A group of sulfur-containing organic compounds.

Oxy-fuel combustion: The process of burning a fuel using pure oxygen instead of air as the primary oxidant.

Polymers: A class of large organic molecules (including natural and synthetic materials) composed of repeating chains or networks linked by carbon-carbon bonds and exhibiting a wide variety of properties.

Saturation pressure: The pressure at a corresponding boiling point where a liquid boils into its vapor phase.

Sinter: A coarse-grained product produced by heating fine grain raw material (powder) below its melting point until its particles adhere to each other. Iron ore sinter is used for charging a blast furnace.

Supercritical $\mathrm{CO}_{2}$ : A fluid state of carbon dioxide where it is held at or above its critical temperature and critical pressure, and where distinct liquid and gas phases do not exist.

Wettability: The affinity of a fluid to spread out on a solid substrate. This is dependent on the surface tension (and contact angle) between the solid surface and a drop of fluid. 



\section{Contents}

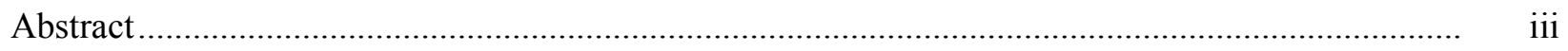

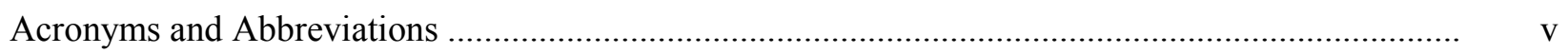

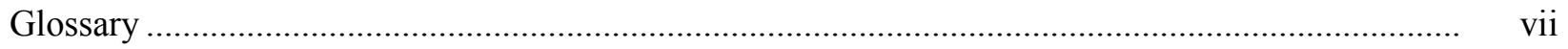

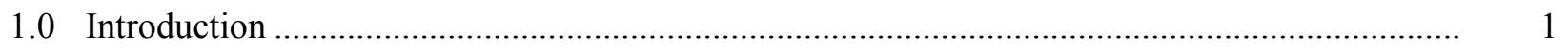

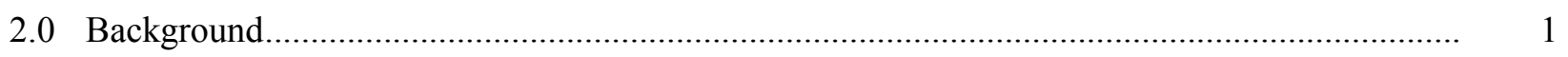

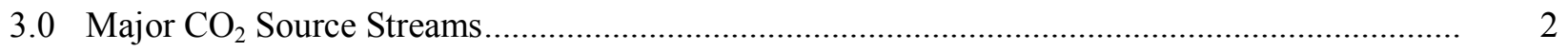

3.1 Major Sources of Anthropogenic $\mathrm{CO}_{2}$ Emissions ........................................................ 2

3.2 Carbon Dioxide Recovery/Capture ............................................................................... 3

3.2.1 Recovery of $\mathrm{CO}_{2}$ from Relatively Pure Sources …............................................

3.2.2 Separation and Capture of $\mathrm{CO}_{2}$ from Dilute Exhaust Gases ................................. 5

4.0 Impurities/Co-Contaminants in $\mathrm{CO}_{2}$ Captured for Geologic Sequestration .............................. 5

4.1 Flue Gas from Coal-Fired Power Plants...................................................................... 8

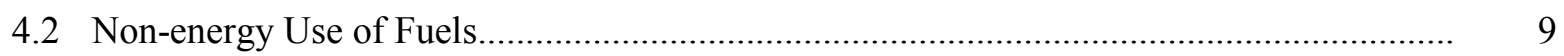

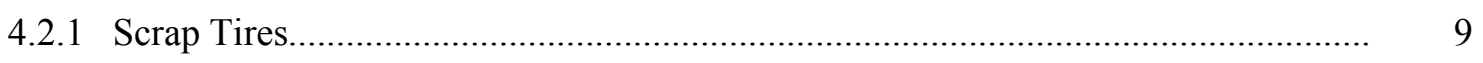

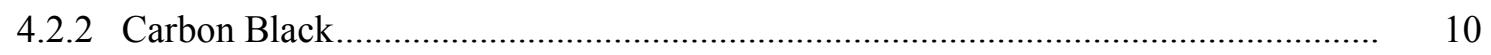

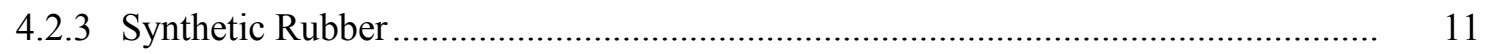

4.3 Iron and Steel, and Metallurgical Coke Production ....................................................... 12

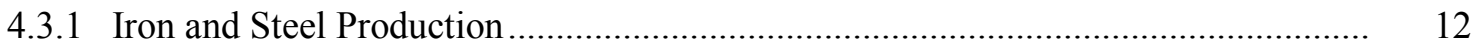

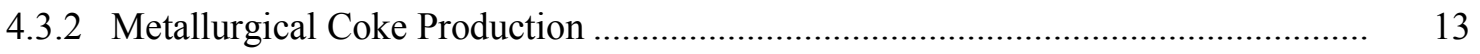

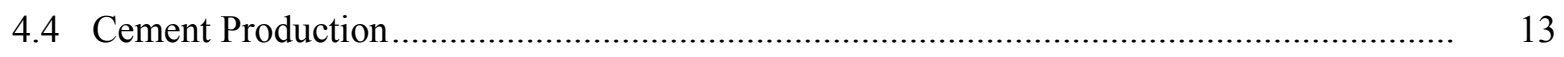

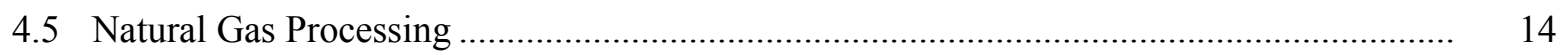

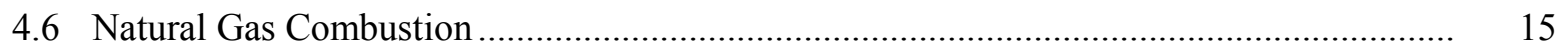

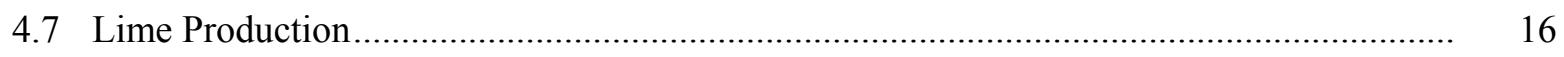

5.0 Selection of $\mathrm{CO}_{2}$ Waste-Stream Compositions for Use in Experimental Studies ...................... 17

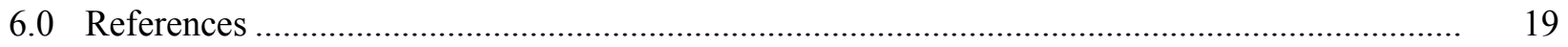




\section{Tables}

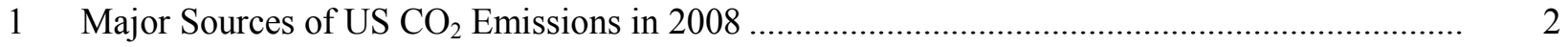

2 Possible Trace Level Impurities in $\mathrm{CO}_{2}$ Source Streams by Source Type................................. 7

3 Relative Concentrations of Flue Gas Impurities in a Separated $\mathrm{CO}_{2}$ Stream ........................... 9

4 Typical Emission Factors for Carbon Black Manufacturing ................................................... 11

5 Typical Composition of Tail Gas from Carbon Black Manufacturing ....................................... 11

6 Emission Factors and Relative Proportions of Combustion Stack Emissions from

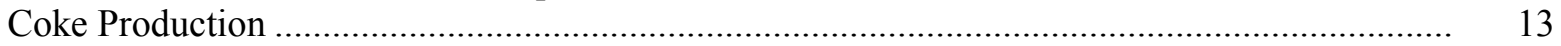

7 Summary of Emission Factors and Relative Proportions for Portland Cement Kilns ................. 14

8 Emission Factors and Relative Proportions from Natural Gas Combustion............................... 15

9 Emission Factors and Relative Proportions of Gases from Lime Manufacturing ...................... 16

10 Concentrations and Relative Proportions of Gases from a Lime Kiln in Alabaster,

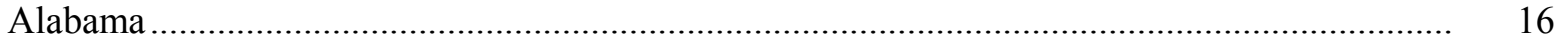

11 Summary of Relative Proportions of Major Impurities in Post Carbon Capture $\mathrm{CO}_{2}$

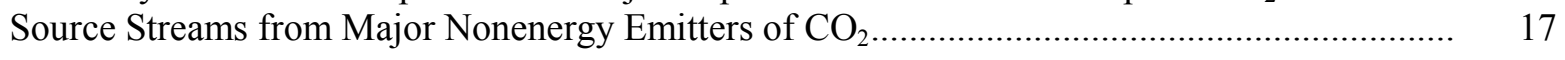

$12 \mathrm{CO}_{2}$ Streams Selected for Investigation by Koenen et al. (2010) ................................................ 18

13 Recommended Test Concentrations in Mole \% ........................................................................ 19 


\subsection{Introduction}

This report summarizes the chemical impurities typically found in major carbon-dioxide $\left(\mathrm{CO}_{2}\right)$ source streams, and identifies some prototypical source stream compositions for use in geochemical experiments. This work supports the American Recovery and Reinvestment Act National Risk Assessment Partnership, aimed at providing scientific basis for risk assessments with respect to the long-term storage of $\mathrm{CO}_{2}$.

The primary objectives of this report are to achieve the following:

- Identify major $\mathrm{CO}_{2}$ source streams from industrial sources outside the power (energy) production industry that contain co-contaminants

- Identify most industrially important co-contaminants to consider in assessing long-term geologic storage of $\mathrm{CO}_{2}$

- Select a few prototypical $\mathrm{CO}_{2}$ waste stream compositions for use in experimental studies.

\subsection{Background}

Geologic sequestration of $\mathrm{CO}_{2}$ is a promising technology for stabilizing atmospheric greenhouse gas concentrations by separating and capturing $\mathrm{CO}_{2}$ from industrial or energy-related sources, transporting it to a storage location, and injecting it deep underground for long-term isolation from the atmosphere. A critical component in the assessment of long-term risk from these activities is the ability to predict mineralogical and geochemical changes within storage reservoirs due to rock-brine- $\mathrm{CO}_{2}$ reactions. Impurities and/or other constituents selected for co-sequestration can affect both the chemical and physical (e.g., density, viscosity, interfacial tension) properties of $\mathrm{CO}_{2}$ in the deep subsurface. The generic $\mathrm{CO}_{2}$ Features, Events and Processes database (Savage et al. 2004) lists the composition of the $\mathrm{CO}_{2}$ source stream(s) as a key feature to be considered for the assessment of long-term performance and safety of geologic storage of $\mathrm{CO}_{2}$.

Numerous studies have been performed using pure supercritical $\mathrm{CO}_{2}$, and some efforts have been expended to examine co-contaminants relevant to power (energy) production. However, few studies have focused on co-contaminants that are unique to major non-energy-related industrial sources. The intent of the American Recovery and Reinvestment Act National Risk Assessment Partnership is to use site-specific materials and $\mathrm{CO}_{2}$ stream compositions (including co-contaminants) from existing or planned large-scale industrial carbon capture and sequestration (CCS) projects to experimentally identify geochemical mechanisms and their impact on long-term risk profiles.

The first step in this effort is to identify the most industrially important co-contaminants and their potential concentrations, and to identify a few prototypical $\mathrm{CO}_{2}$ waste stream compositions for use in these experimental studies. Section 3.0 provides a summary of the major sources of $\mathrm{CO}_{2}$ and an overview of carbon capture technologies. Section 4.0 provides a description of potential impurities/ co-contaminants typically found in stack emissions from the largest non-energy industrial sources. Section 5.0 summarizes some potential post-carbon capture $\mathrm{CO}_{2}$ sequestration source stream concentrations produced from large non-energy industrial sources for possible use in experimental studies. 


\subsection{Major $\mathrm{CO}_{2}$ Source Streams}

$\mathrm{CO}_{2}$ is emitted to the atmosphere both naturally through the carbon cycle and through human activities. The focus of this review is on anthropogenic $\mathrm{CO}_{2}$ emissions (particularly from non-energyrelated industrial sources) and their co-contaminants and concentrations that could be targeted for sequestration. These co-contaminants are a function of both the industrial source(s) of the $\mathrm{CO}_{2}$, as well as the carbon capture technology used to extract the $\mathrm{CO}_{2}$ and produce a concentrated stream that can be compressed into liquid form and readily transported to a geologic sequestration site.

\subsection{Major Sources of Anthropogenic $\mathrm{CO}_{2}$ Emissions}

The predominant source of anthropogenic $\mathrm{CO}_{2}$ emissions is the combustion of fossil fuels (coal, oil and natural gas) in power plants, automobiles, industrial facilities, and other sources (EPA 2010, p. 1-3). Non-energy production processes, such as cement production, metal production, and the use of petroleum-based products also emit notable quantities of $\mathrm{CO}_{2}$. Forest clearing activities and other biomass burning also contribute to $\mathrm{CO}_{2}$ emissions. Table 1 summarizes the major sources of $\mathrm{CO}_{2}$ emission in the United States in 2008.

Table 1. Major Sources of U.S. $\mathrm{CO}_{2}$ Emissions in 2008 (from EPA 2010, Table 2.1)

\begin{tabular}{lc}
\hline \multicolumn{1}{c}{ Source/End-Use Sector } & $\begin{array}{c}\text { Percent of } \mathrm{CO}_{2} \text { Emissions } \\
\text { in the U.S. in 2008 }\end{array}$ \\
\hline $\begin{array}{l}\text { Fossil fuel combustion } \\
\text { - Electricity generation }\end{array}$ & 94.1 \\
$\quad$ - Coal combustion (e.g., flue gas from coal-fired power plants) & 39.9 \\
- Transportation & $34^{(\mathrm{a})}$ \\
- Industrial (primarily associated with producing steam or heat for industrial & 30.2 \\
$\quad$ processes) & 13.8 \\
- Residential & 5.79 \\
- Commercial (primarily associated with electricity consumption for lighting, & \\
$\quad$ heating, cooling, and operating appliances) & 3.71 \\
- U.S. territories & \\
Non-energy use of fuels (e.g., scrap tires, carbon black, and synthetic rubber carbon & 0.72 \\
emissions) & \\
Iron and steel, and metallurgical coke production & 2.27 \\
Cement production & 1.17 \\
Natural gas systems & 0.69 \\
Lime production (e.g., from lime kilns) & 0.51 \\
Incineration of waste & 0.24 \\
\hline
\end{tabular}


Table 1. (contd)

\begin{tabular}{lc}
\hline & Percent of $\mathrm{CO}_{2}$ Emissions \\
Source/End-Use Sector & in the U.S. in 2008 \\
\hline Ammonia production and urea consumption & 0.20 \\
Cropland remaining cropland & 0.13 \\
Limestone and dolomite use & 0.11 \\
Aluminum production & 0.08 \\
Soda ash production and consumption & 0.07 \\
Petrochemical production & 0.06 \\
Titanium dioxide production & 0.03 \\
Carbon dioxide consumption & 0.03 \\
Ferroalloy production & 0.03 \\
Phosphoric acid production & 0.02 \\
Wetlands remaining wetlands ${ }^{(c)}$ & 0.02 \\
Petroleum systems & 0.01 \\
Zinc production & 0.01 \\
Lead production & 0.01 \\
Silicon carbide production and consumption & 0.00 \\
\hline Note that shaded rows identify the focus of this study. & \\
(a) Lee et al. (2009). & \\
(b) Fuel consumption by U.S. territories (i.e., American Samoa, Guam, Puerto Rico, U.S. Virgin Islands, Wake \\
(c) CO $_{2}$ emissions from the removal of biomass and the decay of drained peat. \\
\hline
\end{tabular}

\subsection{Carbon Dioxide Recovery/Capture}

The first step in geologic sequestration of $\mathrm{CO}_{2}$ is to separate the $\mathrm{CO}_{2}$ from other exhaust gases and produce a concentrated stream of $\mathrm{CO}_{2}$ that can be compressed into liquid form and readily transported to a geologic sequestration site. $\mathrm{CO}_{2}$ is routinely separated and captured as a by-product from industrial processes such as synthetic ammonia production, hydrogen $\left(\mathrm{H}_{2}\right)$ production, and limestone calcination, and represents the 19th largest commodity chemical in the United States, based on mass. ${ }^{1}$ However, existing capture technologies are not very effective in producing concentrated $\mathrm{CO}_{2}$ from large air-fired combustion sources - such as power plants - that dilute the $\mathrm{CO}_{2}$ with nitrogen. Flue gas from coal-fired power plants contains $10-12 \% \mathrm{CO}_{2}$ by volume, while flue gas from natural gas combined cycle plants contains only $3-6 \% \mathrm{CO}_{2}{ }^{1}$

For effective carbon sequestration, the $\mathrm{CO}_{2}$ in these exhaust gases must be separated and concentrated. There are a number of technologies available for capturing $\mathrm{CO}_{2}$. When discussed in the context of fossil fuel combustion, they are commonly classified as either pre-combustion or postcombustion systems, depending on whether the $\mathrm{CO}_{2}$ is removed before or after a fuel is burned. The use of carbon capture technologies depends on the specific circumstances under which the capture system is deployed (e.g., the type of plant [pulverized coal or Integrated Gasification Combined Cycle (IGCC) power plant], the vintage and efficiency of the plant, or whether sulfur dioxide $\left(\mathrm{SO}_{2}\right)$, nitrogen oxide

\footnotetext{
${ }^{1}$ http://fossil.energy.gov/programs/sequestration/capture/.
} 
$\left(\mathrm{NO}_{\mathrm{x}}\right)$, and other emissions controls are in place). The most commonly used technology for low concentration $\mathrm{CO}_{2}$ capture is absorption with amine-based chemical solvents (e.g., monoethanolamine [MEA]), adapted from the gas processing industry (GCEP 2005). MEA was developed over 60 years ago as a general, nonselective solvent to remove acid gases, such as $\mathrm{CO}_{2}$ and hydrogen sulfide $\left(\mathrm{H}_{2} \mathrm{~S}\right)$, from natural gas streams (Herzog 1999). The process was modified to incorporate inhibitors to resist solvent degradation and equipment corrosion when applied to $\mathrm{CO}_{2}$ capture from flue gas. If $\mathrm{NO}_{\mathrm{x}}$, sulfur oxides $\left(\mathrm{SO}_{\mathrm{x}}\right)$, or other reactive impurities are present, they are first removed (such as by low $\mathrm{NO}_{\mathrm{x}}$ burners and selective catalytic reduction [SCR]). Otherwise, they can react preferentially with the amines, reducing the capacity for $\mathrm{CO}_{2}$, or irreversibly poisoning the solvent. Rao and Rubin (2002) reported that when $\mathrm{SO}_{2}$ or nitrogen dioxide $\left(\mathrm{NO}_{2}\right)$ react with MEA, they form heat-stable salts that reduce the MEA solvent's capacity for absorbing $\mathrm{CO}_{2} . \mathrm{SO}_{2}$ is more of a concern than $\mathrm{NO}_{\mathrm{x}}$ because in flue gas, the most common form of $\mathrm{NO}_{\mathrm{x}}$ is nitric oxide (NO), which is not reactive with MEA.

There are specific advantages and disadvantages to using any $\mathrm{CO}_{2}$ capture technology (Figueroa et al. 2008). For example, post-combustion technologies are relatively high in cost because $\mathrm{CO}_{2}$ in the treatment stream has been diluted by combustion air. Pre-combustion capture systems are generally aimed at waste streams that contain higher concentrations if $\mathrm{CO}_{2}$. However, precombustion technologies also have high costs. The oxy-fuel combustion capture process involves burning fossil fuels in pure oxygen rather than air, which produces almost pure $\mathrm{CO}_{2}$ with some water vapor. The main problem with this technology is separating the oxygen from the air, which usually requires a lot of energy.

Scholes et al. (2009) states that certain chemical impurities such as $\mathrm{SO}_{\mathrm{x}}$ and $\mathrm{NO}_{\mathrm{x}}$ have a tendency to degrade polymeric membranes used for $\mathrm{CO}_{2}$ capture if they come in contact with water. The amount of impurities found in flue gas and carbon streams need to be considered before carbon capture to ensure the membranes are capable of separating both $\mathrm{CO}_{2}$ and the impurities.

While $\mathrm{SO}_{2}$ can be destructive to the capture process if MEA solvents are used, it has been shown to have little effect on the geologic sequestration process because it has chemical properties very similar to those of $\mathrm{CO}_{2}$ (Scholes et al. 2009). According to Nougueira and Mamora (2008), the injection of $\mathrm{CO}_{2}$ that contains less than one mole \% of chemical impurities would result in practically the same volume of $\mathrm{CO}_{2}$ being sequestered as a stream of pure $\mathrm{CO}_{2}$. Not needing to completely purify emissions would reduce the costs of carbon capture, making carbon capture a more feasible option. Carbon capture for pure $\mathrm{CO}_{2}$ streams, such as those produced from ammonia or ethanol plants, is half the price of $\mathrm{CO}_{2}$ streams that requires the removal of impurities (Herzog and Drake 1996). If a slightly contaminated stream could be injected into the ground for storage with similar results as $\mathrm{CO}_{2}$, the costs of carbon capture for these streams could be potentially reduced by $50 \%$.

\subsubsection{Recovery of $\mathrm{CO}_{2}$ from Relatively Pure Sources}

In a few instances, industrial processes emit relatively pure $\mathrm{CO}_{2}$, which can be separated and captured relatively cheaply. Such processes generally produce $\mathrm{CO}_{2}$ as a commercial byproduct for use in a number of products/industries, such as fire extinguishing systems; soft drink carbonation; freezing or cooling of food products; enhanced oil recovery (EOR); and alkaline water treatment. ${ }^{1}$

\footnotetext{
${ }^{1}$ http://www.uigi.com/carbondioxide.html.
} 
Capturing and producing $\mathrm{CO}_{2}$ as a commercial product generally depends on the availability of a relatively high-volume, $\mathrm{CO}_{2}$-rich gas stream. These streams primarily come from a large-scale chemical production process or biological process. ${ }^{1}$ Typical gas streams used as feedstock for commercially viable liquid $\mathrm{CO}_{2}$ plants come from the manufacture of some fertilizers, natural gas processing, and cement manufacturing. Large quantities of $\mathrm{CO}_{2}$ (at concentrations up to $50 \%{ }^{2}$ ) are produced by lime kilns, which calcine the limestone to produce calcium oxide (lime), and magnesium oxide from dolomite (calcium magnesium carbonate). Other industrial activities that produce large amounts of relatively concentrated $\mathrm{CO}_{2}$ are ammonia production and hydrogen production from natural gas or other hydrocarbon raw materials, corn-to-ethanol plants, and breweries. ${ }^{3}$

$\mathrm{CO}_{2}$ can also be manufactured directly by burning carbonaceous fuels. ${ }^{4}$ However, the concentration of $\mathrm{CO}_{2}$ in stack exhaust gases from simple combustion sources (heaters, boilers, furnaces) is usually not high enough to make $\mathrm{CO}_{2}$ recovery commercially feasible. The economic viability of recovery and purification of $\mathrm{CO}_{2}$ is highly dependent on the source of the $\mathrm{CO}_{2}$ (i.e., whether the $\mathrm{CO}_{2}$ is obtained from a natural source, a fermentation source, or a chemical processing source), the specific impurities found within the raw gas stream, and the end-use of the $\mathrm{CO}_{2}$.

\subsubsection{Separation and Capture of $\mathrm{CO}_{2}$ from Dilute Exhaust Gases}

Most anthropogenic emissions of $\mathrm{CO}_{2}$ come from coal-fired power stations, which can have flue-gas $\mathrm{CO}_{2}$ concentrations as low as 10 to $15 \% .{ }^{5}$ Separating and capturing the $\mathrm{CO}_{2}$ from such exhaust stack gases is complex due to the low concentration of $\mathrm{CO}_{2}$ and the presence of undesirable compounds.

There are several $\mathrm{CO}_{2}$ capture technologies available that can be applied either before (pre-combustion) or after (post-combustion) a fuel is burned (Folger 2010; Sass et al. 2005). The separation/capture technology (e.g., chemical absorption [amines], physical absorption, chemical absorption/flue gas recycling) and its application depend on the desired purity of the $\mathrm{CO}_{2}$ and on the conditions of the source stream being treated (e.g., $\mathrm{CO}_{2}$ and impurity concentrations).

Another approach, oxyfuel or oxy-combustion, burns the fuel using pure oxygen instead of air as the primary oxidant. This process produces less flue gas than air-fueled combustion and flue gas consists primarily of $\mathrm{CO}_{2}$ and water vapor. Thus, this process does not require complicated $\mathrm{CO}_{2}$ capture technology.

\subsection{Impurities/Co-Contaminants in $\mathrm{CO}_{2}$ Captured for Geologic Sequestration}

The composition of $\mathrm{CO}_{2}$ source stream(s) destined for geologic sequestration is a key feature to be considered for the assessment of long-term performance and safety of geologic storage of $\mathrm{CO}_{2}($ Savage et al. 2004). Different combinations of $\mathrm{CO}_{2}$ feedstock and capture/purification technologies result in

\footnotetext{
${ }^{1}$ http://www.uigi.com/co2recovery.html.

${ }^{2} \mathrm{http}: / / \mathrm{www} . c 02 \mathrm{crc} \cdot \mathrm{com} . \mathrm{au} / \mathrm{aboutccs} / \mathrm{capture} \cdot \mathrm{html}$.

${ }^{3}$ http://www.uigi.com.

${ }^{4}$ http://www.infoplease.com/ce6/sci/A0810371.html\#ixzz1HX2WeYz6.

5 http://www.co2crc.com.au/aboutccs/capture.html.
} 
different sets of impurities and ranges in impurity concentrations in these source streams. Savage et al. (2004) infers that impurities such as $\mathrm{H}_{2} \mathrm{~S}$, methane $\left(\mathrm{CH}_{4}\right)$, nitrogen $\left(\mathrm{N}_{2}\right), \mathrm{NO}_{\mathrm{x}}, \mathrm{SO}_{2}$ and mercaptans may be present in $\mathrm{CO}_{2}$ source streams either intentionally or because it could be particularly difficult to separate them from the $\mathrm{CO}_{2}$ feedstock. Savage et al. (2004) further indicates that $\mathrm{NO}_{\mathrm{x}}$ and $\mathrm{SO}_{2}$ might be of particular interest because they are polluting gases that are generated by the same power plants that generate large amounts of $\mathrm{CO}_{2}$ and attract emission taxes in certain countries (e.g., Italy). Their co-injection with $\mathrm{CO}_{2}$, even in small amounts, could help the economics of geologic storage.

Savage et al. (2004) indicated the presence of even small amounts of other gases may have a strong effect on the phase behavior of $\mathrm{CO}_{2}$-dominated gases; these gases must be considered in high-pressure equations of state for $\mathrm{CO}_{2}$-dominated gas mixtures to account for changes in critical pressures and temperatures. Impurities can reduce the critical temperature, which in turn, has effects on interfacial tension. In addition to changes in interfacial tension, impurities may also change the wettability of the rock, which could lead to the rock needing different sealing capacities to contain the $\mathrm{CO}_{2}$ and the chemical impurities ( $\mathrm{Li}$ et al. 2005). Impurities may also affect pore water chemistry (e.g., $\mathrm{pH}$ and redox conditions), depending on the impurities involved.

Sass et al. (2005) identified a large variety of potential impurities in the $\mathrm{CO}_{2}$ source streams for a number of typical $\mathrm{CO}_{2}$ sources (Table 2). Wang et al. (2010) indicates that oxygen $\left(\mathrm{O}_{2}\right)$ (in addition to $\mathrm{N}_{2}, \mathrm{SO}_{2}$, and $\mathrm{H}_{2} \mathrm{~S}$ ) can have negative effects on transport, injection, and storage of $\mathrm{CO}_{2}$. Wang et al. (2010) found that $\mathrm{O}_{2}$ and $\mathrm{N}_{2}$ had the greatest effect on increasing saturation pressure of the liquid and decreasing critical temperatures, but that $\mathrm{SO}_{2}$ decreases the saturation pressure and increases the critical temperature. In addition, $\mathrm{O}_{2}, \mathrm{~N}_{2}$, and $\mathrm{H}_{2}$ significantly reduce the density of supercritical $\mathrm{CO}_{2}$ and the solubility of $\mathrm{CO}_{2}$ in brine by reducing the partial pressure of $\mathrm{CO}_{2}$; both of these effects reduce the overall capacity of the storage reservoir.

From a geochemical perspective, Koenen and Tambach (2011) found that $\mathrm{O}_{2}, \mathrm{H}_{2} \mathrm{~S}, \mathrm{SO}_{2}$, and $\mathrm{NO}_{\mathrm{x}}$ were probably the most important impurities. Even at low concentrations, these impurities can influence the $\mathrm{pH}$ of the formation water, and disturb the geochemical and geomechanical properties of the reservoir rock, cap rock, and well bore material. These impurities were observed to only have significant effects if they accumulated near the injection well. It was further stressed the presence or absence of $\mathrm{O}_{2}$ is of great importance, particularly in the oxidation of $\mathrm{H}_{2} \mathrm{~S}$.

DOE (2007) indicated that impurities in the captured $\mathrm{CO}_{2}$ streams (e.g., argon, water $\left[\mathrm{H}_{2} \mathrm{O}\right], \mathrm{N}_{2}$, and $\mathrm{O}_{2}$ ) may also affect the compressor and pipeline operations. 
Table 2. Possible Trace Level Impurities in $\mathrm{CO}_{2}$ Source Streams by Source Type (Excluding Air Gases and Water)

\begin{tabular}{|c|c|c|c|c|c|c|c|c|}
\hline Component & Combustion & $\begin{array}{c}\text { Wells/ } \\
\text { Geothermal }\end{array}$ & Fermentation & $\begin{array}{c}\text { Hydrogen or } \\
\text { Ammonia }\end{array}$ & $\begin{array}{c}\text { Phosphate } \\
\text { Rock }\end{array}$ & $\begin{array}{c}\text { Coal } \\
\text { Gasification }\end{array}$ & $\begin{array}{l}\text { Ethylene } \\
\text { Oxide }\end{array}$ & $\begin{array}{c}\text { Acid } \\
\text { Neutralization }\end{array}$ \\
\hline Aldehydes & $X$ & $X$ & $X$ & $X$ & & $\mathrm{X}$ & $\mathrm{X}$ & \\
\hline Amines & $\mathrm{X}$ & & & $\mathrm{X}$ & & & & \\
\hline Benzene $\left(\mathrm{C}_{6} \mathrm{H}_{6}\right)$ & $\mathrm{X}$ & $\mathrm{X}$ & $X$ & $\mathrm{X}$ & & $\mathrm{X}$ & $\mathrm{X}$ & $\mathrm{X}$ \\
\hline Carbon monoxide (CO) & $\mathrm{X}$ & $\mathrm{X}$ & $\mathrm{X}$ & $\mathrm{X}$ & $\mathrm{X}$ & $\mathrm{X}$ & $\mathrm{X}$ & $\mathrm{X}$ \\
\hline Carbonyl sulfide (COS) & & $\mathrm{X}$ & $\mathrm{X}$ & $\mathrm{X}$ & $\mathrm{X}$ & $\mathrm{X}$ & & $\mathrm{X}$ \\
\hline Cycloaliphatic hydrocarbons & $X$ & $\mathrm{X}$ & & $\mathrm{X}$ & & $\mathrm{X}$ & $\mathrm{X}$ & \\
\hline Dimethyl sulfide $\left(\left(\mathrm{CH}_{3}\right)_{2} \mathrm{~S}\right)$ & & $\mathrm{X}$ & $X$ & & $\mathrm{X}$ & $\mathrm{X}$ & & $\mathrm{X}$ \\
\hline Ethanol $\left(\mathrm{C}_{2} \mathrm{H}_{5} \mathrm{OH}\right)$ & $\mathrm{X}$ & $\mathrm{X}$ & $\mathrm{X}$ & $\mathrm{X}$ & & $\mathrm{X}$ & $\mathrm{X}$ & \\
\hline Ether & & $\mathrm{X}$ & $\mathrm{X}$ & $\mathrm{X}$ & & $\mathrm{X}$ & $\mathrm{X}$ & \\
\hline Ethyl acetate $\left(\mathrm{CH}_{3} \mathrm{COOCH}_{2} \mathrm{CH}_{3}\right)$ & & $\mathrm{X}$ & $\mathrm{X}$ & & & $\mathrm{X}$ & $\mathrm{X}$ & \\
\hline Ethyl benzene $\left(\mathrm{C}_{6} \mathrm{H}_{5} \mathrm{CH}_{2} \mathrm{CH}_{3}\right)$ & & $\mathrm{X}$ & & $X$ & & $\mathrm{X}$ & $\mathrm{X}$ & \\
\hline Ethylene oxide $\left(\mathrm{C}_{2} \mathrm{H}_{4} \mathrm{O}\right)$ & & & & & & $\mathrm{X}$ & $\mathrm{X}$ & \\
\hline Halocarbons & $\mathrm{X}$ & & & & & $\mathrm{X}$ & $\mathrm{X}$ & \\
\hline Hydrogen cyanide (HCN) & $\mathrm{X}$ & & & & & $\mathrm{X}$ & & \\
\hline Hydrogen sulfide $\left(\mathrm{H}_{2} \mathrm{~S}\right)$ & $\mathrm{X}$ & $\mathrm{X}$ & $\mathrm{X}$ & $\mathrm{X}$ & $\mathrm{X}$ & $\mathrm{X}$ & $\mathrm{X}$ & $\mathrm{X}$ \\
\hline Ketones & $\mathrm{X}$ & $\mathrm{X}$ & $\mathrm{X}$ & $\mathrm{X}$ & & $\mathrm{X}$ & $\mathrm{X}$ & \\
\hline Mercaptans & $\mathrm{X}$ & $\mathrm{X}$ & $\mathrm{X}$ & $\mathrm{X}$ & $\mathrm{X}$ & $\mathrm{X}$ & $\mathrm{X}$ & \\
\hline Mercury (Hg) & $\mathrm{X}$ & & & & & $\mathrm{X}$ & & \\
\hline Nitrogen oxide $\left(\mathrm{NO}_{\mathrm{x}}\right)$ & $\mathrm{X}$ & & $\mathrm{X}$ & $\mathrm{X}$ & & $\mathrm{X}$ & $\mathrm{X}$ & $\mathrm{X}$ \\
\hline Phosphine $\left(\mathrm{PH}_{3}\right)$ & & & & & $\mathrm{X}$ & & & \\
\hline Radon (Rn) & & $X$ & & & $\mathrm{X}$ & & & $\mathrm{X}$ \\
\hline Sulfur dioxide $\left(\mathrm{SO}_{2}\right)$ & $X$ & $\mathrm{X}$ & $X$ & $\mathrm{X}$ & $\mathrm{X}$ & $\mathrm{X}$ & & $\mathrm{X}$ \\
\hline Toluene $\left(\mathrm{C}_{7} \mathrm{H}_{8}\right)$ & & $\mathrm{X}$ & $\mathrm{X}$ & $\mathrm{X}$ & & $\mathrm{X}$ & $\mathrm{X}$ & \\
\hline Vinyl chloride $\left(\mathrm{C}_{2} \mathrm{H}_{3} \mathrm{Cl}\right)$ & $\mathrm{X}$ & & & & & $\mathrm{X}$ & $\mathrm{X}$ & \\
\hline Volatile hydrocarbons & $\mathrm{X}$ & $\mathrm{X}$ & $X$ & $X$ & & $\mathrm{X}$ & $\mathrm{X}$ & \\
\hline Xylene $\left(\mathrm{C}_{6} \mathrm{H}_{4} \mathrm{C}_{2} \mathrm{H}_{6}\right)$ & & $\mathrm{X}$ & $\mathrm{X}$ & $\mathrm{X}$ & & $\mathrm{X}$ & $\mathrm{X}$ & \\
\hline
\end{tabular}


EPA (2011) states the composition of the injectate will be reflected in several chemical and physical parameters assigned to the $\mathrm{CO}_{2}$ fluid in the model simulations. EPA (2011) further indicates that studies by Knauss et al. (2005) and Xu et al. (2007) showed the addition of $\mathrm{H}_{2} \mathrm{~S}$ had little impact on geochemical reactions and mineral trapping (formation of carbonate minerals), but the addition of $\mathrm{SO}_{2}$ resulted in a lower $\mathrm{pH}$ in the injection zone, less carbon-bearing mineral precipitation, and more formation-mineral dissolution.

A review of the major $\mathrm{CO}_{2}$ sources and their specific associated impurities and relative concentrations follows. This review relies mostly on a compilation of air pollutant emission factors (AP-42) taken from the U.S. Environmental Protection Agency's (EPA) Clearinghouse for Inventories \& Emissions Factors. ${ }^{1}$ For the purposes of this study, it is assumed that carbon capture technology applied to the exhaust gas emissions from these facilities removes most of the $\mathrm{N}_{2}, \mathrm{O}_{2}$, and Ar to produce a concentrated $\mathrm{CO}_{2}$ stream $^{2}$ with the same approximate ratio of other impurities (e.g., $\mathrm{NO}_{\mathrm{x}}, \mathrm{SO}_{\mathrm{x}}$ ) to $\mathrm{CO}_{2}$ as the original exhaust emissions.

The focus of this report is on non-energy-related industrial sources of $\mathrm{CO}_{2}$ emissions because few studies have focused on these sources. Many non-energy-related industries use fossil fuels as carbon feedstocks for the manufacture of synthetic material and chemical products, such as plastics, fibers, synthetic rubber, paints, solvents, fertilizers, lubricants, and surfactants. Following a brief overview of the impurities associated with $\mathrm{CO}_{2}$ streams separated from flue gas generated by coal, oil, and natural gas power plants, the authors of this report concentrated on the top five non-energy-related industrial sources of $\mathrm{CO}_{2}$ : non-energy use of fuels (e.g., scrap tires, carbon black, and synthetic rubber carbon emissions); iron, steel, and metallurgical coke production, cement production, natural gas systems, and lime production (e.g., from lime kilns).

\subsection{Flue Gas from Coal-Fired Power Plants}

Sass et al. (2005) found that flue gas derived from combustion of carbon-rich fuel (e.g., coal) may contain $\mathrm{SO}_{\mathrm{x}}, \mathrm{NO}_{\mathrm{x}}$, several different low molecular weight hydrocarbons, carbon monoxide (CO), and mercury, and that concentrations of these impurities may vary greatly.

Lee et al. (2009) estimated concentration of impurities in $\mathrm{CO}_{2}$ streams separated from flue gases of different compositions produced from pulverized coal combustion power plants. Lee et al. (2009) found that flue gas from these plants could range between 10 and 3000 parts per million by volume (ppmv) $\mathrm{SO}_{2}$. Wet flue gas desulfurization (e.g., scrubbed using MEA-based absorption process) could reduce the $\mathrm{SO}_{2}$ concentrations down to 135 ppmv. Heat-stable salt formation could reduce the $\mathrm{SO}_{2}$ concentration to as low as 34 ppmv. Other impurities included sulfur tri-oxide $\left(\mathrm{SO}_{3}\right), \mathrm{NO}_{2}$, hydrogen chloride $(\mathrm{HCl})$, and oxidized mercury.

Table 3 provides an estimate of the relative concentrations of impurities in a $\mathrm{CO}_{2}$ stream separated from flue gas, as modified from Lee et al. (2009) and Sass et al. (2005). Although this study is focused

\footnotetext{
${ }^{1} \mathrm{http}: / /$ www.epa.gov/ttn/chief/ap42/index.html.

2 Impacts of Impurities on $\mathrm{CO}_{2}$ Capture, Transport and Storage. Accessed at http://www.nrac.wvu.edu/projects/sheia/publications/CarbonSequestration/DOE/ImpactImpuritiesonCO2CaptureTra nsportandStorage.pdf.
} 
on the non-energy industrial sources of $\mathrm{CO}_{2}$ for possible sequestration, information on flue gas sources is provided as a means of comparison for how carbon capture technologies might alter relative concentrations of impurities.

Table 3. Relative Concentrations of Flue Gas Impurities in a Separated $\mathrm{CO}_{2}$ Stream (modified from Lee et al. 2009 and Sass et al. 2005)

\begin{tabular}{|c|c|c|c|c|c|}
\hline Component & $\begin{array}{c}\text { Relative } \\
\text { Proportions in } \\
\text { Flue Gas } \\
(\%[\mathrm{v}])\end{array}$ & $\begin{array}{c}\text { Relative } \\
\text { Proportions in } \\
\text { Separated } \mathrm{CO}_{2} \\
\text { Stream Without } \\
\text { Wet Flue Gas } \\
\text { Desulfurization } \\
\text { Scrubber } \\
(\%[\mathrm{w}])^{(\mathrm{a})} \\
\end{array}$ & $\begin{array}{l}\text { Relative Proportions } \\
\text { in Separated } \mathrm{CO}_{2} \\
\text { Stream with Wet Flue } \\
\text { Gas Desulfurization } \\
\text { Scrubber } \\
(\%[\mathrm{w}])^{(\mathrm{a})}\end{array}$ & $\begin{array}{c}\text { Relative Proportions in } \\
\text { Separated } \mathrm{CO}_{2} \text { Stream } \\
\text { with Low } \mathrm{NO}_{\mathrm{x}} \text { Burners, } \\
\text { Selective Catalytic } \\
\text { Reduction, and Wet } \\
\text { Flue Gas } \\
\text { Desulfurization } \\
\text { Scrubber }(\%[\mathrm{w}])^{(\mathrm{a})} \\
\end{array}$ & $\begin{array}{c}\text { Estimated } \\
\text { Concentrations in } \\
\text { Separated } \mathrm{CO}_{2} \\
\text { Stream, Assuming } \\
\text { Amine Adsorption } \\
(\%[\mathrm{v}])^{(\mathrm{b})} \\
\end{array}$ \\
\hline $\mathrm{CO}_{2}$ & 13.5 & 97.45 & 99.8 & 99.8 & 93.2 \\
\hline $\mathrm{SO}_{2}$ & 0.016 & 2.3 & 0.12575 & 0.12575 & Trace \\
\hline $\mathrm{SO}_{3}$ & 0.00325 & 0.0295 & 0.01535 & 0.01535 & Trace \\
\hline $\mathrm{N}_{2}$ & 74.7 & & & & 0.17 \\
\hline $\mathrm{NO}_{2}$ & 0.0025 & 0.00585 & 0.0046 & 0.00185 & \\
\hline $\mathrm{NO}_{\mathrm{x}}$ & 0.06 & & & & Trace \\
\hline $\mathrm{HCl}$ & 0.00525 & 0.0422 & 0.000575 & 0.000575 & \\
\hline $\mathrm{O}_{2}$ & 4 & & & & 0.01 \\
\hline $\mathrm{H}_{2} \mathrm{O}$ & 7.7 & & & & 6.5 \\
\hline Hydrocarbons & Trace $^{(b)}$ & & & & Trace $^{(\mathrm{b})}$ \\
\hline Metals & $\operatorname{Trace}^{(\mathrm{b})}$ & & & & Trace $^{(\mathrm{b})}$ \\
\hline $\mathrm{Hg}(2+)$ & Trace & 0.0000142 & 0.00000145 & 0.00000145 & \\
\hline
\end{tabular}

(a) Estimated values (except mercury) include both with and without salt formation.

(b) After Sass et al. (2005).

\subsection{Non-energy Use of Fuels}

About $5-10 \%$ of fossil fuels are used for chemical conversion processes (of non-energy use). ${ }^{1}$ Non-energy use of fossil fuels for the production of chemicals and certain refinery products results in $\mathrm{CO}_{2}$ emissions throughout the life cycle in the industrial production, and during product use and subsequent waste treatment. This includes the first use of fossil fuels to create products such as lubricants, paraffin waxes, bitumen/asphalt, and solvents, and secondary uses or disposal of these products after first use (i.e., the combustion of waste oils such as used lubricants). For purposes of this study, the research was focused on three main industries: scrap tire, carbon black, and synthetic rubber.

\subsubsection{Scrap Tires}

Two to three billion $\left(2-3 \times 10^{9}\right)$ scrap tires are in landfills and stockpiles across the United States, with approximately one scrap tire per person generated every year (Reisman 1997). The synthetic rubber in scrap tires consists of about $90 \%$ carbon (Freed et al. 2005). $\mathrm{CO}_{2}$ emissions primarily come from

\footnotetext{
${ }^{1}$ http://nws.chem.uu.nl/nenergy/.
} 
uncontrolled open burning and or controlled burning of the scrap tires as a source of fuel. Tire-derived fuels (TDF) are used in energy-intensive industries (such as cement kilns) as a source of renewable energy. Only the latter provides an opportunity for $\mathrm{CO}_{2}$ capture and its impurities.

An analysis performed on the rubber portion of passenger car tires indicated they are generally made of carbon, hydrogen, ash, oxygen, sulfur, and nitrogen (EPA 1992). Emissions from burning of scrap tires include a variety of organic and inorganic compounds, many of which may pose health risks. There is a limited amount of emission data available with which to estimate emission factors (EPA 1997). However, use of TDF is similar to the use of coal. TDF has a higher heating value than coal, less moisture content, more carbon, about as much sulfur as medium-sulfur coal, and much less fuel-bound nitrogen.

Because the most likely source of $\mathrm{CO}_{2}$ emissions suitable for capture and sequestration comes from using TDF as an energy source via a dilute exhaust stream. Refer to flue gas emissions (Section 4.1) for an approximation of exhaust gas concentrations.

\subsubsection{Carbon Black}

Carbon black is a fine black amorphous form of carbon, generally 10 to $500 \mathrm{~nm}$ in diameter. It is principally used as a reinforcing agent in rubber compounds such as tires, and as a black pigment in inks, surface coatings, paper, and plastics. The tire industry consumes around $80 \%$ of the total carbon black (Hisazumi 2006). About $90 \%$ of the carbon black manufactured in the United States is produced using an oil furnace process (EPA 1983). Here, an aromatic liquid hydrocarbon feedstock is heated and injected continuously into the combustion zone of a natural gas-fired furnace, where it decomposes to elemental carbon in the form of carbon black. However, typical emissions from this process include particulate matter, $\mathrm{CO}$, organics, $\mathrm{NO}_{\mathrm{x}}$, sulfur compounds, polycyclic organic matter, and trace elements. The principal source of emissions is from the main process vent, and emissions may vary considerably according to the grade of the carbon black being manufactured, and the chemical makeup of the feedstock. Typical emission factors for carbon black manufacturing, using an oil furnace process, are shown in Table 4.

Hisazumi (2006) indicated the imperfect combustion of carbon black oil (or feedstock) converts half of the hydrocarbons into carbon black while the other half goes into the tail gas. Hisazumi (2006) also indicated the typical composition of this tail gas as shown in Table 5.

Carbon capture technologies for the dilute exhaust gas from carbon black manufacturing would probably resemble those used with flue gas (from coal, oil, or gas-fired power plants) and would likely result in similar levels of impurities. 
Table 4. Typical Emission Factors for Carbon Black Manufacturing

\begin{tabular}{|c|c|}
\hline Component & Emissions, $\mathrm{kg} / \mathrm{kg}$ \\
\hline $\mathrm{CO}_{2}$ & $1.9^{(\mathrm{a})}$ to $3.75^{(\mathrm{b})}$ \\
\hline $\mathrm{H}_{2} \mathrm{~S}$ & 30 \\
\hline $\mathrm{SO}_{\mathrm{x}}$ & 25 (from flare) \\
\hline $\mathrm{NO}_{\mathrm{x}}$ & 0.28 \\
\hline $\mathrm{CH}_{4}$ & 25 \\
\hline Non-methane VOC & 50 \\
\hline
\end{tabular}

From EPA (1983), Table 6.1-3.

(a) Neelis et al. (2005).

(b) From National Grid and Atlantic Hydrogen, Inc. (2009) ${ }^{1}$.

Table 5. Typical Composition of Tail Gas from Carbon Black Manufacturing (from Hisazumi 2006)

\begin{tabular}{|c|c|}
\hline Component & Emissions, vol. \% \\
\hline $\mathrm{CO}_{2}$ & $2.4-4.9^{(\mathrm{a})}$ \\
\hline $\mathrm{CO}$ & $10.2-11^{(\mathrm{a})}$ \\
\hline $\mathrm{N}_{2}$ & 36.2 \\
\hline $\mathrm{H}_{2}$ & 8.0 \\
\hline $\mathrm{CH}_{4}$ & 0.2 \\
\hline $\mathrm{H}_{2} \mathrm{O}$ & 43.0 \\
\hline
\end{tabular}

\subsubsection{Synthetic Rubber}

Synthetic rubber is an artificial elastomer with the mechanical (or material) property that allows it to undergo much more elastic deformation than most materials and still return to its previous size without permanent deformation. Synthetic rubber is generally made from the polymerization of a variety of monomers including styrene and butadiene. These and other monomers can be mixed in various proportions with other impurities or additives to achieve a wide range of physical, mechanical, and chemical properties.

There are two types of polymerization reactions used to produce styrene-butadiene copolymers - the emulsion type and the solution type (EPA 1982). During these processes, the condenser tail gases (noncondensables and volatile organic compound [VOC] vapors [mostly styrene and butadiene]) are vented to the atmosphere. The estimated emission factor for VOCs from the emulsion latex process is $8.45 \mathrm{~g} / \mathrm{kg}$ of copolymer produced (EPA 1982). An estimated $6 \mathrm{~kg}$ of $\mathrm{CO}_{2}$ is released to the air for every $1 \mathrm{~kg}$ from plastic produced. ${ }^{2}$ A similar level of $\mathrm{CO}_{2}$ release is assumed for the manufacture of

\footnotetext{
${ }^{1}$ National Grid and Atlantic Hydrogen, Inc. 2009. Hydrogen-Enriched Natural Gas, Bridge to an Ultra-Low Carbon World. Accessed at http://www.ffydd.org/documents/congresspapers/225.pdf.

${ }^{2}$ http://www.powerplantccs.com/ccs/cap/fut/c2p/plastics.html.
} 
synthetic rubber. The San Joaquin Valley Air Pollution Control District found only VOCs in area and point source emissions for rubber and rubber products manufacturing. ${ }^{1}$ They reported zero emissions for $\mathrm{NO}_{\mathrm{x}}, \mathrm{CO}$, and $\mathrm{SO}_{\mathrm{x}}$.

The carbon content of synthetic rubber is estimated at $90 \%$ for tire synthetic rubber and $85 \%$ for nontire synthetic rubber. ${ }^{2}$ Approximately $2.5 \mathrm{lb}$ per passenger tire and $10 \mathrm{lb}$ per commercial tire are assumed to be abraded from the tires during use and considered to be $100 \%$ emitted (presumably as $\mathrm{CO}_{2}$ ). Other than the abraded rubber, no other emissions from the use of synthetic rubber were identified. ${ }^{3}$

Based on this study, the authors of this report have been unable to find relative proportions of impurities in a potential $\mathrm{CO}_{2}$ source stream for carbon sequestration from the manufacture or use of synthetic rubber other than as a TDF (see Section 4.2.1).

\subsection{Iron and Steel, and Metallurgical Coke Production}

Iron and steel production is an energy-intensive activity that also generates process-related emissions of $\mathrm{CO}_{2}, \mathrm{CH}_{4}$, and other gasses. Process emissions occur at each step of the production process. Metallurgical coke is an important component of this process. Coke is used to produce iron or pig iron from raw iron ore, and is produced both onsite at "integrated" iron and steel plants and offsite at "merchant" coke plants.

\subsubsection{Iron and Steel Production}

Steel production at an integrated iron and steel plant is accomplished using several interrelated processes. The major operations are as follows: 1) coke production; 2) sinter production; 3 ) iron production; 4) iron preparation; 5) steel production; 6) semi-finished product preparation; 7) finished product preparation; 8) heat and electricity supply; and 9) handling and transport of raw, intermediate, and waste materials.

EPA (2010, p. 50) indicated the vast majority of greenhouse gases (i.e., $\mathrm{CO}_{2}$ ) from steel production is emitted from blast furnace stove stacks where the combustion gases from the stoves are discharged. A small amount of emissions may also occur from flares, leaks in the ductwork for conveying the gas, and from blast furnace emergency venting. Emissions of $\mathrm{CO}_{2}$ are also generated from the combustion of natural gas using flame suppression to reduce emissions of particulate matter. It was estimated in EPA (2010) that the relative composition of blast furnace gas contains about $60 \%$ nitrogen, $28 \% \mathrm{CO}$, and $12 \%$ $\mathrm{CO}_{2}$. Carbon capture technology applied to this dilute $\mathrm{CO}_{2}$ exhaust stream would likely produce similar impurity estimates to those of flue gas (Section 4.1).

\footnotetext{
${ }^{1} 2008$ Area Source Emissions Inventory Methodology; 410 - Rubber, Fiberglass and Plastics Manufacturing, San Joaquin Valley Air Pollution Control District.

${ }^{2}$ EPA (2011). ANNEX 2, "Methodology and Data for Estimating CO2 Emissions from Fossil Fuel Combustion," p. A-93-A-94. Accessed at http://www.epa.gov/climatechange/emissions/downloads11/US-GHG-Inventory-2011Annex-2.pdf.

${ }^{3}$ EPA (2011). ANNEX 2, "Methodology and Data for Estimating CO2 Emissions from Fossil Fuel Combustion," p. A-93-A-94. Accessed at http://www.epa.gov/climatechange/emissions/downloads11/US-GHG-Inventory-2011Annex-2.pdf.
} 


\subsubsection{Metallurgical Coke Production}

Metallurgical coke is used in iron and steel industry processes (primarily in blast furnaces) to reduce iron ore to iron. Metallurgical coke is produced by destructive distillation of coal in coke ovens, in an oxygen-free atmosphere (-coked-) until most volatile components are removed. Most coke plants are colocated with iron and steel production facilities, and the demand for coke generally corresponds with the production of iron and steel. ${ }^{1}$ An estimate of the relative proportions of concentrated (post carbon capture) combustion stack gases from coke production is provided in Table 6 (from EPA 2008).

Table 6. Emission Factors and Relative Proportions of Combustion Stack Emissions from Coke Production

\begin{tabular}{lcc}
\hline \multicolumn{1}{c}{ Component } & Emissions, $\mathrm{kg} / \mathrm{Mg}$ & Relative Proportion \\
\hline Extractable organic matter & 0.012 & $0.00247 \%$ \\
$\mathrm{CO}$ & 0.34 & $0.07010 \%$ \\
$\mathrm{CO}_{2}(\mathrm{BFG})$ & 482 & $99.37313 \%$ \\
$\mathrm{NO}_{\mathrm{x}}$ & 0.82 & $0.16906 \%$ \\
$\mathrm{SO}_{\mathrm{x}}(\mathrm{DCOG})$ & 1.47 & $0.30307 \%$ \\
$\mathrm{HCl}(\mathrm{DCOG})$ & 0.013 & $0.00268 \%$ \\
Total organic compounds & 0.19 & $0.03917 \%$ \\
Methane $\left(\mathrm{CH}_{4}\right)$ & 0.1 & $0.02062 \%$ \\
Ethane & 0.005 & $0.00103 \%$ \\
Acetone & 0.0295 & $0.00608 \%$ \\
VOC & 0.047 & $0.00969 \%$ \\
Benzene & 0.0075 & $0.00155 \%$ \\
Toluene & 0.0033 & $0.00068 \%$ \\
Chloromethane & 0.0032 & $0.00066 \%$ \\
Benzoic acid & $4.14 \mathrm{E}-05$ & $0.00001 \%$ \\
Bis $(2$-ethylhexyl)phthalate & $3.40 \mathrm{E}-06$ & $0.00000 \%$ \\
Diethyl phtalate & $9.90 \mathrm{E}-06$ & $0.00000 \%$ \\
2,4-Dimethylphenol & $4.17 \mathrm{E}-06$ & $0.00000 \%$ \\
Phenol & $2.56 \mathrm{E}-06$ & $0.00000 \%$ \\
\hline BFG = Blast furnace gas. & & \\
DCOG = Desulfurized coke oven gas. & & \\
VOC = Volatile organic compound. & & \\
\hline
\end{tabular}

\subsection{Cement Production}

Portland cement accounts for $95 \%$ of the hydraulic cement production in the United States (EPA 1995a). Portland cement consists of a mixture of calcium silicates, aluminates,

\footnotetext{
${ }^{1}$ EPA (U.S. Environmental Protection Agency). "Fact Sheet Final Rule to Reduce Toxic Air Emissions From Lime Manufacturing Plants." Accessed at www.epa.gov/ttn/atw/lime/limefs8-19-03.pdf.
} 
aluminoferrites. More than 30 raw materials are known to be used in the manufacture of Portland cement, the most notable of which is limestone. These materials are chemically combined through pyroprocessing and subjected to subsequent mechanical processing operations.

$\mathrm{NO}_{\mathrm{x}}, \mathrm{SO}_{2}, \mathrm{CO}$, and $\mathrm{CO}_{2}$ are the primary gaseous emissions in the manufacture of Portland cement. Small quantities of VOC, ammonia $\left(\mathrm{NH}_{3}\right)$, chlorine, and $\mathrm{HCl}$ may also be emitted. Emissions may also include products of incomplete combustion that are considered to be hazardous. Because some facilities burn waste fuels, particularly spent solvents in the kiln, these systems may also emit small quantities of additional hazardous organic pollutants. Also, raw material feeds and fuels typically contain trace amounts of heavy metals that may be emitted as a particulate or vapor (EPA 1995a).

In addition, calcium oxide $(\mathrm{CaO})$ is produced from concrete plants and has been shown capable of being stored with sequestered $\mathrm{CO}_{2}$ (Stolaroff et al. 2005). $\mathrm{CaO}$ reacts with $\mathrm{CO}_{2}$ to create $\mathrm{CaCO}_{3}$, which has proven to be a stable compound that can be stored safely underground. In the presence of water, $\mathrm{CaO}$ also reacts relatively quickly with $\mathrm{CO}_{2}$ so it is not difficult to create this compound. This is also an option for steel plants because high levels of $\mathrm{CaO}$ are present in steel slag.

Emission factors from Portland cement kilns and their relative proportions expected in a concentrated (post-carbon capture) $\mathrm{CO}_{2}$ source stream are summarized in Table 7.

Table 7. Summary of Emission Factors and Relative Proportions for Portland Cement Kilns (from EPA 1995a)

\begin{tabular}{lcc}
\hline \multicolumn{1}{c}{ Component } & Max. Emissions, $\mathrm{kg} / \mathrm{Mg}$ & Relative Proportion \\
\hline Total organic carbon & 0.09 & $0.00810 \%$ \\
$\mathrm{CO}$ & 1.8 & $0.16208 \%$ \\
$\mathrm{CO}_{2}$ & 1100 & $99.04792 \%$ \\
$\mathrm{NO}_{\mathrm{x}}$ & 3.7 & $0.33316 \%$ \\
$\mathrm{SO}_{2}$ & 4.9 & $0.44121 \%$ \\
$\mathrm{HCl}$ & 0.073 & $0.00657 \%$ \\
Acetone & 0.00019 & $0.00002 \%$ \\
Benzene & 0.008 & $0.00072 \%$ \\
Toluene & 0.0001 & $0.00001 \%$ \\
Chloromethane & 0.00019 & $0.00002 \%$ \\
Benzoic acid & $1.80 \mathrm{E}-03$ & $0.00016 \%$ \\
Bis(2-ethylhexyl)phthalate & $4.80 \mathrm{E}-05$ & $0.00000 \%$ \\
Phenol & $5.50 \mathrm{E}-05$ & $0.00000 \%$ \\
Hg & $1.10 \mathrm{E}-04$ & $0.00001 \%$ \\
\hline
\end{tabular}

\subsection{Natural Gas Processing}

Raw natural gas is usually passed through field separators at the wellhead to remove hydrocarbon condensate and water. Natural gas contains a number of impurities, principally $\mathrm{CO}_{2}$ and $\mathrm{H}_{2} \mathrm{~S}$, that must be removed before a number of separable commodities can be utilized. This is called "sweetening" the gas. The typical mole percent of $\mathrm{CO}_{2}$ remaining in the processed natural gas is reportedly about 
$0.6 \mathrm{~mol} \%{ }^{1}$ Major emission sources in natural gas processing come from compressor engines, acid gas wastes, fugitive emissions from leaking equipment, and glycol dehydrator vent streams (if present). Most plants employ elevated smokeless flares or tail gas incinerators for complete combustion of all waste gas constituents, including virtually $100 \%$ conversion of the $\mathrm{H}_{2} \mathrm{~S}$ to $\mathrm{SO}_{2}$. Thus, the major pollutant is $\mathrm{SO}_{2}$. The emission factor for $\mathrm{SO}_{2}$ from gas sweetening plants is $26.98 \mathrm{~kg} / 10^{3} \mathrm{~m}^{3}$ gas produced, while those for $\mathrm{CO}$ and $\mathrm{NO}_{\mathrm{x}}$ are negligible (EPA 1995b). Due to the high level of impurities and low levels of $\mathrm{CO}_{2}$, it is unlikely that natural gas processing plants would be targeted for carbon capture and sequestration, at least in the near future.

\subsection{Natural Gas Combustion}

Natural gas is one of the major fuels used to generate electric power, produce industrial process steam and heat, and heat commercial and residential buildings. Natural gas contains a high percentage (generally $<85 \%$ ) of $\mathrm{CH}_{4}$ and varying amounts of ethane, propane, butane, and inerts (typically $\mathrm{N}_{2}, \mathrm{CO}_{2}$, and helium) (EPA 1998a). There are three major types of boilers used for natural gas combustion for utility and industrial purposes: watertube, firetube, and cast iron. Residential boilers and furnaces are generally similar to firetube boilers. The emissions from natural gas-fired boilers and furnaces include $\mathrm{NO}_{x}, \mathrm{CO}, \mathrm{CO}_{2}, \mathrm{CH}_{4}, \mathrm{~N}_{2} \mathrm{O}$, VOCs, trace amounts of $\mathrm{SO}_{2}$, and particulate matter (EPA 1998a). A number of control techniques (both during and after combustion) are used to reduce these emissions (particularly $\mathrm{NO}_{\mathrm{x}}$ ). For the purposes of developing emission factors, EPA organized natural gas combustion processes into three categories: large wall-fired boilers, boilers and residential furnaces, and tangential-fired boilers. Emission factors, in lb/million standard cubic feet (scf) of natural gas fired, are summarized in Table 8.

Table 8. Emission Factors and Relative Proportions from Natural Gas Combustion (from EPA 1998a)

\begin{tabular}{lcc}
\hline & Maximum Emissions, & \\
$\mathrm{lbs} / 10^{6}$ scf & Relative Proportion \\
\hline $\mathrm{CO}_{2}$ & 120,000 & 99.7 \\
$\mathrm{CO}$ & 98 & 0.0814 \\
$\mathrm{~N}_{2} \mathrm{O}$ & 2.2 & 0.00183 \\
$\mathrm{SO}_{2}$ & 0.6 & 0.0005 \\
$\mathrm{NO}_{\mathrm{x}}$ & 280 & 0.233 \\
$\mathrm{CH}_{4}$ & 2.3 & 0.00191 \\
$\mathrm{VOC}$ & 5.5 & 0.00457 \\
$\mathrm{TOC}$ & 11 & 0.00914 \\
Lead & 0.0005 & 0.00000 \\
\hline Taken from EPA (1998a), Table 1.4-2. & \\
\hline
\end{tabular}

\footnotetext{
${ }^{1}$ Picard D. "Fugitive Emissions from Oil and Natural Gas Activities." Good Practice Guidance and Uncertainty Management in National Greenhouse Gas Inventories. Accessed at www.ipccnggip.iges.or.jp/public/gp/bgp/2_6_Fugitive_Emissions_from_Oil_and_Natural_Gas.pdf.
} 


\subsection{Lime Production}

Lime is produced through calcination of limestone, dolomite or other natural materials. The center of lime production is the lime kiln, and the most prevalent type of kiln is the rotary kiln, accounting for about $90 \%$ of all lime production in the United States (EPA 1998b). $\mathrm{CO}_{2}, \mathrm{CO}, \mathrm{SO}_{2}$, and $\mathrm{NO}_{\mathrm{x}}$ are all produced in lime kilns. Emissions are influenced by the content of the fuel used to heat the kiln, content and mineralogic form of the feed material, quality of the lime produced, type of kiln used, and type of pollution control equipment used. An estimate of the relative proportions of these gases expected in a concentrated (post-carbon capture) $\mathrm{CO}_{2}$ source stream is provided in Table 9 (from EPA 1998b).

Table 9. Emission Factors and Relative Proportions of Gases from Lime Manufacturing

\begin{tabular}{ccc}
\hline Component & Emission Factor $(\mathrm{kg} / \mathrm{Mg})$ & Relative Percent \\
\hline $\mathrm{SO}_{2}$ & 2.7 & $0.17 \%$ \\
$\mathrm{SO}_{3}$ & 0.11 & $0.01 \%$ \\
$\mathrm{NO}_{\mathrm{x}}$ & 1.7 & $0.11 \%$ \\
$\mathrm{CO}$ & 3.2 & $0.20 \%$ \\
$\mathrm{CO}_{2}$ & 1600 & $99.52 \%$ \\
\hline
\end{tabular}

The primary air toxics present in the exhaust gases from lime kilns are metals such as arsenic, cadmium, chromium, and nickel, and $\mathrm{HCl}^{1}{ }^{1}$

An example of lime kiln exhaust gas emission concentrations comes from EPA testing of a lime kiln in Alabaster, Alabama, in 1998 (EPA 2000), Table 10. Note these data would be concentrations/relative proportions prior to carbon capture.

Table 10. Concentrations and Relative Proportions of Gases from a Lime Kiln in Alabaster, Alabama

\begin{tabular}{|c|c|c|c|c|c|}
\hline Component & $\begin{array}{c}\text { Maximum } \\
\text { Concentration }\end{array}$ & $\begin{array}{c}\text { Minimum } \\
\text { Concentration }\end{array}$ & $\begin{array}{c}\text { Average } \\
\text { Concentration }\end{array}$ & Units & $\begin{array}{l}\text { Relative } \\
\text { Proportion }\end{array}$ \\
\hline $\mathrm{O}_{2}$ & & & 10 & $\%$ by volume (assumed) & $23.5379 \%$ \\
\hline $\mathrm{CO}_{2}$ & & & 20 & $\%$ by volume (assumed) & $47.0758 \%$ \\
\hline Moisture & 21.1 & 20 & 20.467 & $\%$ by volume & $29.3447 \%$ \\
\hline Total TCDD & & & ND & $\mathrm{ng} / \mathrm{dscm}$ & \\
\hline Total TCDF & & & ND & $\mathrm{ng} / \mathrm{dscm}$ & \\
\hline $\mathrm{HCl}$ & 1.33 & 0.968 & 1.11 & ppmvd & $0.0261 \%$ \\
\hline Ammonia (as $\mathrm{NH}_{4}$ ) & 0.433 & 0.257 & 0.326 & ppmvd & $0.0077 \%$ \\
\hline Aluminum, $\mathrm{Al}$ & & & ND & ppmvd & \\
\hline Calcium, $\mathrm{Ca}$ & & & 0.13 & ppmvd & $0.0031 \%$ \\
\hline Magnesium, Mg & & & 0.042 & ppmvd & $0.0010 \%$ \\
\hline Potassium, K & & & 0.045 & ppmvd & $0.0011 \%$ \\
\hline Sodium, $\mathrm{Na}$ & & & 0.115 & ppmvd & $0.0027 \%$ \\
\hline
\end{tabular}

\footnotetext{
${ }^{1}$ EPA. "Fact Sheet Final Rule to Reduce Toxic Air Emissions From Lime Manufacturing Plants." Accessed at www.epa.gov/ttn/atw/lime/limefs8-19-03.pdf.
} 


\subsection{Selection of $\mathrm{CO}_{2}$ Waste-Stream Compositions for Use in Experimental Studies}

The co-contaminants and concentrations in $\mathrm{CO}_{2}$ source streams that could be targeted for geologic sequestration are a function of both the industrial source(s) of the $\mathrm{CO}_{2}$, as well as the carbon capture technology used to extract the $\mathrm{CO}_{2}$. Previous sections addressed relative concentrations of $\mathrm{CO}_{2}$ and other constituents in exhaust gases from major non-energy-related industrial sources of $\mathrm{CO}_{2}$, based on reviews of available information from both published and unpublished literature. Consistent information on stack emissions was difficult to find for most industries, so the authors of this report relied mostly on a compilation of air pollutant emission factors (AP-42) taken from EPA's Clearinghouse for Inventories \& Emissions Factors. ${ }^{1}$ It was also assumed that carbon capture technology applied to these industrial exhaust gases streams would remove most of the air $\left(\mathrm{N}_{2}, \mathrm{O}_{2}\right.$, and Ar) to produce a concentrated $\mathrm{CO}_{2}$ stream with the same approximate ratio of other impurities (e.g., $\mathrm{NO}_{\mathrm{x}}, \mathrm{SO}_{\mathrm{x}}$ ) to $\mathrm{CO}_{2}$ as the original exhaust emissions. This is a similar approach to that used by the International Energy Agency's (IEA) Greenhouse Gas Research and Development (IEA GHG R\&D) program. ${ }^{2}$ Table 11 summarizes the relative proportions of the major impurities assumed to be present in post-carbon capture $\mathrm{CO}_{2}$ source streams from major non-energy-related industries contributing to $\mathrm{CO}_{2}$ emissions that could be targeted for geologic sequestration.

Table 11. Summary of Relative Proportions of Major Impurities in Post Carbon Capture $\mathrm{CO}_{2}$ Source Streams from Major Non-energy Emitters of $\mathrm{CO}_{2}$

\begin{tabular}{|c|c|c|c|c|c|}
\hline Component & $\begin{array}{l}\text { Flue Gas with Flue } \\
\text { Gas Desulfurization }\end{array}$ & $\begin{array}{l}\text { Combustion Stack } \\
\text { from Coke Production }\end{array}$ & $\begin{array}{c}\text { Portland Cement } \\
\text { Kilns }\end{array}$ & $\begin{array}{l}\text { Natural Gas } \\
\text { Combustion }\end{array}$ & $\begin{array}{c}\text { Lime } \\
\text { Production }\end{array}$ \\
\hline $\mathrm{CO}_{2}$ & $97.50000 \%$ & $99.40000 \%$ & $99.00000 \%$ & $99.70000 \%$ & $99.52000 \%$ \\
\hline $\mathrm{CO}$ & & $0.07010 \%$ & $0.16200 \%$ & $0.08140 \%$ & $0.20000 \%$ \\
\hline $\mathrm{N}_{2} \mathrm{O}$ & & & & $0.00183 \%$ & \\
\hline $\mathrm{NO}_{2}$ & $0.00585 \%$ & & & & \\
\hline $\mathrm{NO}_{\mathrm{x}}$ & & $0.16900 \%$ & $0.33300 \%$ & $0.23300 \%$ & $0.11000 \%$ \\
\hline $\mathrm{HCl}$ & $0.04220 \%$ & $0.00268 \%$ & $0.00657 \%$ & & \\
\hline $\mathrm{SO}_{2}$ & $2.30000 \%$ & & $0.44100 \%$ & $0.00050 \%$ & $0.17000 \%$ \\
\hline $\mathrm{SO}_{3}$ & $0.02950 \%$ & & & & $0.01000 \%$ \\
\hline $\mathrm{SO}_{\mathrm{x}}$ & & $0.30300 \%$ & & & \\
\hline $\mathrm{CH}_{4}$ & & $0.02060 \%$ & & $0.00191 \%$ & \\
\hline VOC & & $0.00969 \%$ & & $0.00457 \%$ & \\
\hline TOC & & & $0.00810 \%$ & $0.00914 \%$ & \\
\hline Lead & & & & $0.00000 \%$ & \\
\hline $\begin{array}{l}\text { Mercury } \\
(\mathrm{Hg}[2+])\end{array}$ & $0.00001 \%$ & & $0.00001 \%$ & & \\
\hline
\end{tabular}

${ }^{1} \mathrm{http}: / /$ www.epa.gov/ttn/chief/ap42/index.html.

2 Impacts of Impurities on $\mathrm{CO}_{2}$ Capture, Transport and Storage. Accessed at http://www.nrac.wvu.edu/projects/sheia/publications/CarbonSequestration/DOE/ImpactImpuritiesonCO2CaptureTra nsportandStorage.pdf. 
Also reviewed were $\mathrm{CO}_{2}$ sequestration source stream concentrations evaluated by other researchers; it was found that Koenen et al. (2010) had selected two possible $\mathrm{CO}_{2}$ streams for investigating the effects of impurities on geologic sequestration (see Table 12).

Table 12. $\mathrm{CO}_{2}$ Streams Selected for Investigation (by Koenen et al. 2010)

\begin{tabular}{lcc}
\hline \multicolumn{1}{c}{ Component } & Pre-Combustion & Semipurified Oxyfuel \\
\hline $\mathrm{CO}_{2}$ & $99.64000 \%$ & $98.00000 \%$ \\
$\mathrm{CO}$ & $0.00300 \%$ & $0.00500 \%$ \\
$\mathrm{O}_{2}$ & $0.04500 \%$ & $0.70000 \%$ \\
$\mathrm{~N}_{2}$ & $0.07700 \%$ & $0.70000 \%$ \\
$\mathrm{NO}$ & - & $0.01000 \%$ \\
$\mathrm{H}_{2}$ & $0.14000 \%$ & - \\
$\mathrm{H}_{2} \mathrm{~S}$ & $0.00014 \%$ & - \\
$\mathrm{SO}_{2}$ & - & $0.00700 \%$ \\
$\mathrm{Ar}$ & - & $0.60000 \%$ \\
\hline
\end{tabular}

Yang et al. (2007) examined the effect of three different injection gases (pure $\mathrm{CO}_{2}$, impure $\mathrm{CO}_{2}$ containing $5.19 \mathrm{~mol} \% \mathrm{O}_{2}$, and impure $\mathrm{CO}_{2}$ containing $9.99 \mathrm{~mol} \% \mathrm{O}_{2}$ ) on miscible $\mathrm{CO}_{2}$ flooding. Yang et al. (2007) found the minimum miscibility pressures for the tested oils increase unfavorably as the $\mathrm{O}_{2}$ concentration in the $\mathrm{CO}_{2}$ stream increased.

In selecting possible fluid concentrations for use in geochemical experiments, the authors of this report chose to include a test fluid representative of food-grade $\mathrm{CO}_{2}$ as a control. Nearly pure, food-grade $\mathrm{CO}_{2}$ is used for most EOR projects (Bryant and Lake 2005), and is often used as the base case for evaluation of carbon sequestration. Battelle (2002) ${ }^{1}$ found commercial food-grade $\mathrm{CO}_{2}$ has a minimum purity of $99.90 \%$. Nobles and Swenson (1984) found the final product of food-grade $\mathrm{CO}_{2}$ must not have more than $35 \mathrm{ppm} \mathrm{CH}_{4}$ (preferably no more than 5-10 ppm), $10 \mathrm{ppm} \mathrm{CO}, 5 \mathrm{ppm} \mathrm{SO}$, preferably no more than $0.1 \mathrm{ppm} \mathrm{H}_{2} \mathrm{~S}, 0.5 \mathrm{ppm}$ carbonyl sulfide, and $1 \mathrm{ppm}$ total sulfur content. The first test fluid composition was selected to equal $100 \% \mathrm{CO}_{2}$, to be representative of a food-grade $\mathrm{CO}_{2}$ carbon sequestration source stream (Table 12).

The IEA GHG R\&D program ${ }^{2}$ found the most important impurities expected in co-captured $\mathrm{CO}_{2}$ were $\mathrm{H}_{2} \mathrm{~S}$ and $\mathrm{SO}_{2}$, with $\mathrm{NO}_{\mathrm{x}}$ and $\mathrm{CO}$ also listed as other significant impurities. The authors of this report used a similar approach, assuming the incondensable gases in $\operatorname{air}\left(\mathrm{O}_{2}, \mathrm{~N}_{2}\right.$, and $\left.\operatorname{Ar}\right)$ are removed from the $\mathrm{CO}_{2}$ waste streams, leaving $\mathrm{SO}_{2}$ and $\mathrm{NO}_{\mathrm{x}}$ as the main impurities. Drawing from a summary of relative proportions of various nonenergy-related industrial sources, the authors found carbon capture from most sources (except from cement production) would produce similar concentrations, not too different from that of food-grade $\mathrm{CO}^{2}$ with greater than $99 \% \mathrm{CO}_{2}$. Thus, the authors selected their second test fluid composition to be representative of the cement production industry (Table 13).

\footnotetext{
${ }^{1}$ Battelle. 2002. Purity Specifications for Commodity Uses of Carbon Dioxide in the United States. Battelle, Columbus, Ohio.

${ }^{2}$ Impacts of Impurities on $\mathrm{CO}_{2}$ Capture, Transport and Storage. Accessed at www.nrac.wvu.edu/projects/sheia/ publications/CarbonSequestration/DOE/ImpactImpuritiesonCO2CaptureTransportandStorage.pdf.
} 
To provide some diversity for testing purposes, the authors of this report also selected a test fluid composition that might be representative of concentrations coming from flue gas (Test Fluid 3, Table 13), and a test concentration that might be representative of a combined $\mathrm{CO}_{2} / \mathrm{H}_{2} \mathrm{~S}$ stream for co-sequestration (Test Fluid 4, Table 13). Although $\mathrm{H}_{2} \mathrm{~S}$ concentrations as high as 21 mole $\%$ have been used for EOR (Bryant and Lake 2005), most co-capture source streams (such as those from IGCC) plants are expected to be about 3 mole \% (Haines et al. 2004); thus, a similar concentration for Test Fluid 4 was selected (Table 13).

Table 13. Recommended Test Concentrations in Mole \%

\begin{tabular}{lcccc}
\hline Component & $\begin{array}{c}\text { Test Fluid 1 - Food } \\
\text { Grade } \mathrm{CO}_{2}\end{array}$ & $\begin{array}{c}\text { Test Fluid 2 } \\
\text { Cement Production }\end{array}$ & $\begin{array}{c}\text { Test Fluid 3 - Flue } \\
\text { Gas }\end{array}$ & $\begin{array}{c}\text { Test Fluid 4- } \\
\text { Co-Captured } \mathrm{CO}_{2} \\
\text { and } \mathrm{H}_{2} \mathrm{~S}\end{array}$ \\
\hline $\mathrm{CO}_{2}$ & $100.0 \%$ & $99.0 \%$ & $97.5 \%$ & $97.0 \%$ \\
$\mathrm{NO}_{\mathrm{x}}\left(\mathrm{NO}_{2}\right)$ & & $0.5 \%$ & & \\
$\mathrm{SO}_{2}$ & & $0.5 \%$ & $2.5 \%$ & \\
$\mathrm{H}_{2} \mathrm{~S}$ & & & $3.0 \%$ \\
\hline
\end{tabular}

\subsection{References}

Bryant S and LW Lake. 2005. "Effect of Impurities on Subsurface $\mathrm{CO}_{2}$ Storage Processes." Chapter 18 in Carbon Dioxide Capture for Storage in Deep Geologic Formations, Vol. 2, eds DC Thomas and SM Benson, pp. 983-996, Elsevier Ltd.

DOE (U.S. Department of Energy). 2007. FutureGen Project Final Environmental Impact Statement. DOE/EIS-0394, National Energy Technology Laboratory, U.S. Department of Energy, Washington, D.C.

EPA (U.S. Environmental Protection Agency). 1982. "Synthetic Rubber.” AP 42, Fifth Edition, Volume I, Chapter 6, Organic Chemical Process Industry, Section 6.10, U.S. Environmental Protection Agency, Washington, D.C.

EPA. 1983. "Carbon Black.” AP 42, Fifth Edition, Volume I, Chapter 6, Organic Chemical Process Industry, Section 6.1, U.S. Environmental Protection Agency, Washington, D.C.

EPA. 1992. Emission Factor Documentation for AP-42, Section 2.4, Open Burning." Office of Air Quality Planning and Standards, Office of Air and Radiation, U.S. Environmental Protection Agency, Research Triangle Park, North Carolina. (Section was renumbered as 2.5 in the $5^{\text {th }}$ edition.)

EPA. 1995a. "Portland Cement Manufacturing." AP 42, Fifth Edition, Volume I, Chapter 11, Mineral Products Industry, Section 11.6, U.S. Environmental Protection Agency, Washington, D.C.

EPA. 1995b. "Natural Gas Processing." AP 42, Fifth Edition, Volume I, Chapter 5, Petroleum Industry, Section 5.3, U.S. Environmental Protection Agency, Washington, D.C. 
EPA. 1997. Air Emissions from Scrap Tire Combustion. EPA-600/R-97-115, Office of Air Quality Planning and Standards, Research Triangle Park, North Carolina, and Office of Research and Development, U.S. Environmental Protection Agency, Washington, D.C.

EPA. 1998a. "Natural Gas Combustion." AP 42, Fifth Edition, Volume I, Chapter 1, External Combustion Sources, Section 1.4, U.S. Environmental Protection Agency, Washington, D.C.

EPA. 1998b. "Lime Manufacturing.” AP 42, Fifth Edition, Volume I, Chapter 11, Mineral Products Industry, Section 11.17, U.S. Environmental Protection Agency, Washington, D.C.

EPA. 2000. Final Report, Manual Testing Lime Kiln No. 1 Scrubber Inlet and Stack, Chemical Lime Company, Alabaster, Alabama. EPA-454/R-00-014, Office of Air Quality Planning and Standards, U.S. Environmental Protection Agency, Research Triangle Park, North Carolina.

EPA. 2008. “Coke Production.” AP 42, Fifth Edition, Volume I, Chapter 12, Metallurgical Industry, Section 12.2, U.S. Environmental Protection Agency, Washington, D.C.

EPA. 2010. Inventory of U.S. Greenhouse Gas Emissions and Sinks. EPA 430-R-10-006, U.S. Environmental Protection Agency, Washington, D.C.

EPA. 2011. Inventory of U.S. Greenhouse Gas Emissions and Sinks: 1990 - 2009. EPA 430-R-11005, U.S. Environmental Protection Agency, Washington, D.C.

Figueroa JD, T Fout, S Plasynski, H Mllvrled, and RD Srivastava. 2008. "Advances in $\mathrm{CO}_{2}$ Capture Technology-The U.S. Department of Energy's Carbon Sequestration Program." International Journal of Greenhouse Gas Control 2(1):9-20. Accessed June 16, 2011, at http://www.sciencedirect.com/science/article/pii/S1750583607000941.

Folger P. 2010. Carbon Capture: A Technology Assessment. 7-5700, R41325 Congressional Research Service, Washington, D.C. Accessed June 16, 2011, at http://www.cmu.edu/epp/iecm/rubin/PDF\%20files/2010/CRS_Carbon\%20Capture\%20Tech\%20Assessm

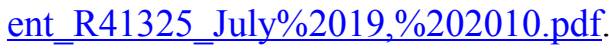

Freed R, C Mintz, R Lanza, and L Hockstad. 2005. "Analytic Framework for Analyzing Non-Energy Uses of Fossil Fuels as Petrochemical Feedstocks in the USA." In Resource, Conservation and Recycling 45(3):275-294.

GCEP (Global Climate and Energy Project). 2005. An Assessment of Carbon Capture Technology and Research Opportunities. Issued by the Global Climate and Energy Project. Accessed June 16, 2011, at http://gcep.stanford.edu/pdfs/assessments/carbon capture assessment.pdf.

Haines M, J Leslie, and D Macdonald. 2004. "Co-Capture and Storage of CO2 With Other Impurities From Coal and Heavy Fuel-Fired Power Plant Flue Gases." In 7th International Conference on Greenhouse Gas Technologies, Vancouver, Canada, September 5-9, 2004.

Herzog HJ and EM Drake. 1996. "Carbon Dioxide Recovery and Disposal from Large Energy Systems." Annual Reviews, Vol. 21 145-166. Accessed June 16, 2011, at http://www.annualreviews.org/doi/full/10.1146/annurev.energy.21.1.145. 
Herzog, H. 1999. Introduction to CO2 Separation and Capture Technologies. MIT Energy Laboratory, Cambridge, Massachusetts. Accessed June 16, 2011, at www.me.unm.edu/ mammoli/ME561_stuff/introduction to capture.pdf

Hisazumi, Y. 2006. "Carbon Blank Manufacturing: Challenges and Opportunities in View of Global Warming." In First Regional Symposium on Carbon Management, Dhahran, Saudi Arabia, May 24, 2006. Accessed June 16, 2011, at http://www.co2management.org/symposium_program.php

Knauss KG, JW Johnson, and CI Steefel. 2005. "Evaluation of the Impact of $\mathrm{CO}_{2}$, Co-contaminant Gas, Aqueous Fluid and Reservoir Rock Interactions on the Geologic Sequestration of $\mathrm{CO}_{2}$." Chemical Geology, 217:339-350.

Koenen M, TJ Tambach, and FP Neele. 2010. "Geochemical Effects of Impurities in $\mathrm{CO}_{2}$ on a Sandstone Reservoir.” Energy Procedia, Vol. 4, pp. 5343-5349.

Koenen M and T Tambach. 2011. "Geochemical Effects of Impurities in $\mathrm{CO}_{2}$ on Long-Term Storage Integrity.” Geophysical Research Abstracts, Vol. 13, EGU2011-3320-1, EGU General Assembly.

Lee J, TC Keener, and YJ Yang. 2009. "Impacts of Flue Gas Impurities in Sequestered CO2 on Groundwater Sources: A Process Analysis and Implications for Risk Management.” Paper \#19, University of Cincinnati and National Risk Management Research Laboratory, Cincinnati, Ohio. Accessed June 16, 2011, at secure.awma.org/presentations/Mega08/Papers/a19 1.pdf.

Li S, M Dong, Z Li, S Huang, H Qing, and E Nickel. 2005. “Gas Breakthrough Pressure for Hydrocarbon Reservoir Seal Rocks: Implications for the Security of Long-Term $\mathrm{CO}_{2}$ Storage in the Weyburn Field." Geofluids: Vol. 5, pp. 326-334.

Neelis ML, M Patel, DJ Gielen, and K Blok. 2005. "Modeling CO2 Emissions from Non-Energy Use With the Non-Energy Use Emission Accounting Tables (NEAT) Model." Resources, Conservation and Recycling, Vol. 45:3 226-250. Accessed June 16, 2011, at http://www.sciencedirect.com/science/article/pii/S0921344905000728.

Nobles JE and LE Swenson. 1984. "Method and Apparatus for Producing Food Grade Carbon Dioxide." U.S. Patent 4460395. Accessed June 16, 2011, at http://www.google.com/patents?hl=en\&lr=\&vid=USPAT4460395\&id.

Nougueira, M. and D. Mamora. 2008. "Effect of Flue Gas Impurities on the Process of Injection and Storage of $\mathrm{CO}_{2}$ in Depleted Gas Reservoirs." Journal of Energy Resources Technology, Vol. 130:1.

Rao A, E Rubin. 2002. "A Technical, Economic, and Environmental Assessment of Amine-Based $\mathrm{CO}_{2}$ Capture Technology for Power Plant Greenhouse Gas Control." Environmental Science and Technology, Vol. 36:20 4467-4475. Accessed June 16, 2011, at http://pubs.acs.org/doi/full/10.1021/es0158861.

Reisman, J. I. 1997. Air Emissions From Scrap Tire Combustion. EPA-600/R-97-115. U.S. Environmental Protection Agency, Washington, DC 
Sass B, B Monzyk, S Ricci, A Gupta, B Hindin, and N Gupta. 2005. Impact of SO $\mathrm{S}_{x}$ and $\mathrm{NO}_{x}$ in Flue Gas on $\mathrm{CO}_{2}$, Separation, Compression, and Pipeline Transmission. Chapter 17 in Carbon Dioxide Capture for Storage in Deep Geologic Formations, Vol. 2. DC Thomas and SM Benson (Eds.). Elsevier, Ltd.

Savage D, PR Maul, S Benbow, and RC Walke. 2004. A Generic FEP Database for the Assessment of Long-Term Performance and Safety of the Geological Storage of $\mathrm{CO}_{2}$. Quintessa Report QRS-1060A-1. Accessed June 16, 2011, at http://www.co2captureandstorage.info/docs/QuintessaReportIEA.pdf.

Scholes C, S Kentish, G Stevens. 2009. "Effects of Minor Components in Carbon Dioxide Capture Using Polymeric Gas Separation Membranes." Separation and Purification Reviews, Vol. 38:1 1-44. Accessed June 16, 2011, at http://www.informaworld.com/smpp/section.

Stolaroff J, G Lowry, and D Keith. 2005. "Using CaO and MgO-Rich Industrial Waste Streams for Carbon Sequestration." Energy Conversion and Management, Vol. 46:5 687-699. Accessed June 16, 2011, at http://www.sciencedirect.com/science/article/pii/S0196890404001190.

TRW Systems Group. 1970. Air Pollutant Emission Factors. PB-206 924, TRW Systems Group, McLean, Virginia; National Technical Information System and National Air Pollution Control Administration, Washington, D.C.

Wang J, D Ryan, EJ Anthony, N Wildgust, and T Aiken. 2010. "Effects of Impurities on $\mathrm{CO}_{2}$ Transport, Injection and Storage.” In International Acid Gas Injection Symposium 2010, AGIS2010-016, Calgary, Canada. Accessed June 16, 2011, at AGIS2010.spheretechconnect.com.

Xu T, JA Apps, K Pruess, and H Yamamoto. 2007. "Numerical Modeling of Injection and Mineral Trapping of $\mathrm{CO}_{2}$ with $\mathrm{H}_{2} \mathrm{~S}$ and $\mathrm{SO}_{2}$ in a Sandstone Formation." Chemical Geology, Vol. 242, pp. 319-346.

Yang, F, G Zhao, H Adidharma, B Towler, M Radosz. 2007. "Effect of Oxygen on Minimum Miscibility Pressure in Carbon Dioxide Flooding." American Chemical Society, Vol. 46:4, pp. 1396-1401. 


\section{Distribution}

No. of

Copies

1 Ronald W. Breault pdf National Energy Technology Laboratory ronald.breault@,netl.doe.gov

1 Grant Bromhal

National Energy Technology Laboratory MS 26/305

3610 Collins Ferry Road

Morgantown, WV 26507-0880

1 George Guthrie

Office of Research and Development

National Energy Technology Laboratory

U.S. Department of Energy

626 Cochrans Mill Road

Pittsburgh, PA 15236-0940

1 William Wierzbicki pdf National Energy Technology Laboratory william.wierzbicki@,ur.netl.doe.gov
No. of

$\underline{\text { Copies }}$

10 Local Distribution

Pacific Northwest National Laboratory

BN Bjorntad

CF Brown (1)

K Cantrell (2)

GV Last

N Qafoku

MT Schmick

H Shao

C Thompson pdf

K6-81

K6-81

pdf

pdf

pdf

pdf

pdf

Distr.1 




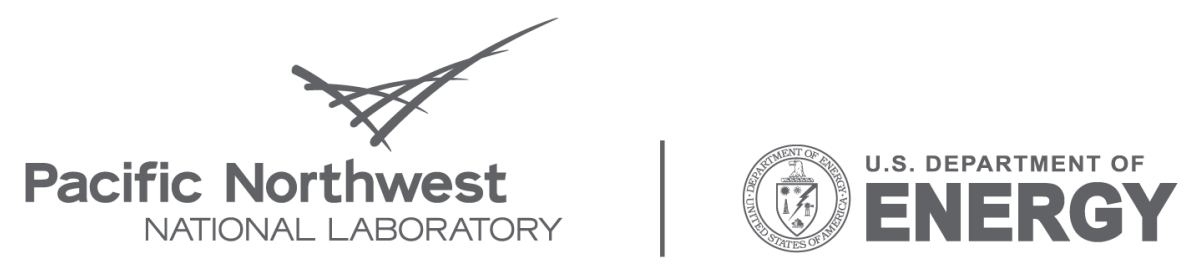

Proudly Operated by Battelle Since 1965

902 Battelle Boulevard

P.O. Box 999

Richland, WA 99352

1-888-375-PNNL (7665)

www.pnl.gov 